\title{
Analisis Teori Pemasaran Pada Perilaku Konsumen Terhadap Kualitas Manajemen Pelayanan Jasa PT. Bank Rakyat Indonesia
}

\author{
Warseno $^{1}$, Ageng Setiani Rafika ${ }^{2}$, Yusuf Firdaus ${ }^{3}$ \\ ${ }^{1}$ Program Studi Akuntansi Universitas Raharja, ${ }^{2}$ Program Studi Sistem Komputer Universitas \\ Raharja, ${ }^{3}$ Program Studi Sistem Komputer \\ Email : warseno@ raharja.info, agengsetianirafika@ raharja.info,"3yusuf.firdaus@raharja.info
}

\section{Pendahuluan}

Pada dasarnya eksistensi Bank di Indonesia saat ini sangat diperlukan karena kehadirannya kini sudah menjadi sebuah kebutuhan dan menjadi tempat ketergantungan bagi setiap warga negara yang ingin memiliki simpanan uang serta menabung untuk menjaga keuangan masa depannya. Selain itu, posisi Bank dulunya dapat digambarkan sebagai cara modernisasi untuk keluar masuknya uang yang lebih baik, aman, dan terjaga. Karena, jika ditinjau dengan cara terdahulunya orang-orang menabung menggunakan celengan secara konvensional atau disimpan pada tempat tertentu yang dianggap aman namun tidak menjanjikan karena kualitas uang perlu dijaga agar tetap dapat dipergunakan dalam bertransaksi jual-beli barang baik secara online maupun secara konvensional (secara langsung). Maka dari itu, atas pemaparan hal tersebut kini era serba modernisasi ini telah banyak perusahaan Bank yang tersebar dan berkembang hal ini dikarenakan banyaknya nilai-nilai kesadaran yang dimiliki oleh setiap individu baik sebagai konsumen maupun nasabah yang nantinya memanfaatkan jasa pelayanan dalam perusahaan Bank tersebut. Dalam hal ini, penulis akan menetapkan parameter yang berfokus pada perusahaan Bank Rakyat Indonesia yang merupakan salah satu Bank yang statusnya milik lembaga pemerintah yang cukup besar di Indonesia dan dalam hal penulisan ini akan berfokus pada manajemen branding dari lembaga Bank BRI tersebut.

Dalam pemahaman lainnya pengertian mengenai eksistensi Bank juga diselaraskan dengan ketentuan pasal 1 angka 2 Undang-Undang Nomor 10 Tahun 1998 yang membahas dengan menjelaskan perubahan atas Undang-Undang Nomor 7 tahun 1992 mengenai Perbankan, yakni Bank merupakan badan atau lembaga usaha yang secara dasar menghimpun dana-dana dari seluruh lapisan masyarakat baik dalam bentuk wadah simpanan ataupun bentuk saluran bantuan dana yang dipinjamkan kepada masyarakat dalam bentuk kredit dan bentuk lainnya dalam rangka memenuhi ekspektasi membentuk kehidupan taraf masyarakat yang lebih baik dan layak dengan kualitas kehidupan yang lancar di masa yang akan datang. Dalam paparan lainnya yakni Prof. G.M. Verryn Stuart juga menegaskan bahwa Bank sebagai badan yang bertujuan untuk memuaskan kebutuhan kredit, baik dengan alat-alat pembayarannya sendiri atau dengan uang yang diperolehnya dari orang lain sehingga menjadi satu kesatuan sistem. Sehingga pada akhirnya nanti Bank akan dioperasionalkan dengan dilihat dari segi kualitas pelayanan jasa yang diberikan baik dalam variabel aktor yang berperang sebagai teller, ataupun jasa lainnya.

Dalam menjalankan kegiatan operasional lembaga Bank harus dipertegaskan pula kualitas pelayanan jasa yang diberikan nantinya selama jam operasional kerja berlangsung. Setiap aktor yang berperan dalam meningkatkan serta menjaga kualitas pelayanan jasa di lembaga Bank ini sangat bergantung dari setiap aktor yang berperan di dalamnya misalnya seperti seorang teller kita dapat mengamati bahwa setiap bentuk informasi yang akan diberikan maupun disampaikan akan diperoleh melalui teller tersebut. Teller ada salah satu petugas Bank yang akan mendengarkan kebutuhan jasa apa yang diinginkan oleh client atau nasabah inginkan. Sehingga pada akhirnya, penulis ingin mempertegas bahwa selain teller juga terdapat 
pelayanan Customer services yang juga merupakan bagian dari pelayanan jasa bank yang bertanggung jawab melayani setiap nasabah yang menginginkan bantuan atau informasi apapun yang berkaitan dengan operasional lembaga Bank tersebut. Sehingga atas pemaparan hal tersebut dapat diketahui bahwa salah satu komponen terpenting dari Bank adalah kegiatan pelayanannya dan maka dari itu pentingnya menjaga kualitas pelayanan jasa dalam Bank juga dapat mempengaruhi cara pandang konsumen yang bertindak sebagai nasabah dalam memberikan sebuah penilaian.

Dalam penulisan ini, Konsumen atau orang yang bertindak sebagai nasabah Bank tersebut akan sangat berharga kehadirannya dalam memberikan omset bagi perusahaan Bank ini dikarenakan itu akan mendapatkan penambahan nilai dalam angka nasabahnya dan semakin meningkatkan nilai rasa percaya dari masyarakat terhadap Bank tersebut. Hal ini juga dipertegas dalam pernyataan (Engel dkk dalam Tjiptono, 2004) yang menyatakan bahwa definisi kehadiran konsumen akan bisa dianalisis dari kepuasannya sebagai nasabah karena hal itu akan menjadi evaluasi purna beli penting dalam kegiatan operasional Bank karena terdapat nilai alternatif yang dipilih sekurang-kurangnya sama atau bisa melewati ekspetasi harapan dari para pelanggan, sedangkan nantinya jika ketidakpuasan ini timbul maka itu merupakan hasil (Outcome) yang tidak bisa memenuhi ekspektasi ataupun harapan dari para nasabah tersebut. Dalam Studi ilmu komunikasi penulis meyakini bahwa bagian dari keberhasilan maupun kesuksesan seorang pelanggan yang setia dan terus berlangganan di suatu perusahaan adalah karena bisa mempercayai sistem pelayanan jasa yang diberikan selalu memenuhi ekspektasi pelanggan dan mengikuti perkembangan zaman atau bersifat fleksibel. Sehingga akan sangat penting keberadaan esensi perilaku konsumen yang menjadi nilai bagi suatu perusahaan Bank seperti Bank BRI (Bank Rakyat Indonesia).

Berdasarkan pemaparan yang telah disampaikan oleh penulis sebelumnya, maka dari itu dalam penulisan makalah kali ini penulis akan menetapkan pembahasan pada judul "Analisis Teori komunikasi Pemasaran Pada Perilaku Konsumen Terhadap Kualitas Manajemen Pelayanan Jasa PT. Bank Rakyat Indonesia" dengan fokus parameter pada Perusahaan Bank Rakyat Indonesia (BRI).

Rumusan Masalah

Berdasarkan pemaparan isu latar belakang yang telah disampaikan oleh penulis pada pendahuluan tersebut. Maka dari itu, dalam penulisan makalah yang berjudul "Analisis Teori komunikasi Pemasaran Pada Perilaku Konsumen Terhadap Kualitas Manajemen Pelayanan Jasa PT. Bank Rakyat Indonesia" ini penulis akan menetapkan beberapa rumusan permasalahan diantaranya, sebagai berikut :

1. Bagaimana strategi sistem manajemen PT. Bank Rakyat Indonesia dalam melayani konsumen?

2. Bagaimana perilaku konsumen terhadap kualitas pelayanan jasa perusahaan Bank Rakyat Indonesia (BRI) saat ini?

Tujuan Penulisan

Berdasarkan pemaparan isu rumusan masalah yang telah ditetapkan tersebut. Maka dari itu, dalam penulisan makalah yang berjudul "Analisis Teori komunikasi Pemasaran Pada Perilaku Konsumen Terhadap Kualitas Manajemen Pelayanan Jasa PT. Bank Rakyat Indonesia" ini penulis akan menyampaikan beberapa tujuan penulisan makalah ini diantaranya, sebagai berikut :

1. Penulis memiliki tujuan untuk menjelaskan strategi sistem manajemen Branding PT. Bank Rakyat Indonesia dalam melayani konsumen yang digunakan saat ini.

2. Penulis memiliki tujuan untuk menjelaskan perilaku konsumen terhadap kualitas pelayanan jasa perusahaan Bank Rakyat Indonesia (BRI) saat ini melalui penggunaan teori komunikasi pemasaran yang merupakan salah satu teori dalam studi kajian Ilmu Komunikasi. 


\section{Metode Penelitian}

Dalam proses pengerjaan penelitian ini, penulis akan menggunakan metode penelitian dengan teknik deskriptif yang berfokus pada penggunaan data kualitatif berdasarkan keadaan yang sebenarnya mengenai kondisi pelayanan jasa dari perusahaan Bank Rakyat Indonesia tersebut. Metode ini akan membantu penulis untuk menjelaskan suatu peristiwa atau fenomena kasus yang saling berkaitan baik yang terjadi di kondisi masa lalu maupun yang kondisi yang terjadi di era sekarang ini. Hal ini sesuai dengan pernyataan Sugiyono dalam bukunya yang berjudul metode penelitian kualitatif kemudian menyatakan bahwa metode penelitian yang berlandaskan pada filsafat postpositivisme, digunakan untuk meneliti pada kondisi obyek yang alamiah, dalam hal ini penulis yang berperan sebagai peneliti bertugas untuk mengatur instrumen kunci, pengambilan sampel sumber data dilakukan secara purposive dan snowball, teknik pengumpulan dengan triangulasi (gabungan), analisis data bersifat induktif atau kualitatif, dan hasil penelitian kualitatif lebih menekankan makna daripada generalisasi.

Penulis akan menggunakan metode penelitian kualitatif ini untuk menjelaskan objek dari kontribusi konsumen dalam menganalisa perilakunya dalam memberikan nilai pada kualitas pelayanan baik atau buruknya pada pelayanan jasa perusahaan Bank Rakyat Indonesia tersebut. Penulis juga menemukan keselarasan dengan adanya dukungan pernyataan (Levy, 2002:131) yakni yang menjelaskan bahwa metode penelitian kualitatif umumnya juga menggunakan teknik dengan cara menelusuri informasi dari buku, literatur, jurnal penelitian, serta dari website berita yang berkaitan dengan permasalahan yang dibahas dalam penelitian ini. Sehingga nantinya berdasarkan dari penjelasan teknik analisis ini penulis bisa lebih menganalisis secara konseptual mengenai perilaku konsumen terhadap kualitas pelayanan jasa perusahaan Bank Rakyat Indonesia tersebut.

\section{Hasil Dan Pembahasan}

\section{Strategi Sistem Manajemen PT. Bank Rakyat Indonesia dalam Melayani Konsumen (Nasabah).}

Pada dasarnya, penulis meyakini bahwa setiap Bank pasti memiliki strategi sistem manajemennya tersendiri dalam mengatur kelancaran kegiatan operasional Bank tersebut. Hal ini dikarenakan dilakukan demi menjaga kinerja kualitas pelayanan jasa Bank tetap baik selain itu hal ini juga dilakukan untuk menjaga reputasi perusahaan Bank agar tetap lebih baik setiap harinya. Maka dari itu, berdasarkan pemaparan tersebut terdapat beberapa hal penting pada strategi manajemen yang digunakan oleh perusahaan Bank Rakyat Indonesia dalam menjaga kualitas pelayanannya pada konsumen atau aktor yang berperan sebagai nasabah dalam pembahasan ini. Penulis mempertegas bahwa pada dasarnya yang dimaksudkan sebagai sistem manajemen dalam perusahaan Bank Rakyat Indonesia ini yakni memiliki makna sebagai bagian dari proses terselenggaranya unsur-unsur penting yang masing-masing komponennya memiliki fungsional tertentu demi kelancaran operasional pada perusahaan Bank Rakyat Indonesia demi mencapai tujuan perusahaan BRI ini. Maka dari itu, dalam strategi sistem manajemen yang diterapkan oleh perusahaan Bank Rakyat Indonesia ini sedari awal didasari oleh kesadaran akan kualitas dan dalam semua kegiatannya secara pasti berorientasi pada kualitas yang berintegritas baik dari sisi produk maupun jasa yang dijual. Sehingga, setiap bentuk interaksi karyawan maupun leader dalam proses memanajemen pekerjaan pelayanan jasa ini akan selalu dievaluasi setiap ada kekurangan ataupun masukan dan berupa kritikan secara langsung maupun tidak langsung yang berasal dari customer maupun nasabah. Setiap bentuk strategi manajemen di perusahaan Bank Rakyat Indonesia ini akan bersifat komprehensif atau bersifat menyeluruh demi mencapai keberhasilan operasional perusahaan Bank Rakyat Indonesia tersebut.

Maka dari itu, dalam strategi yang digunakan oleh perusahaan Bank Rakyat Indonesia ini terdiri atas dua jenis pelayanan yakni, 
a) Pelayanan pelayanan Internal yang merupakan jenis pelayanan yang diberikan dan disampaikan oleh karyawan atau petugas Bank secara internal perusahaan meliputi pemenuhan kebutuhan seperti yang berasal dari masing-masing kantor cabang, kantor cabang pembantu, dan BRI Unit. Diantaranya terdapat petugas Bank yang berperan sebagai teller yang melayani transaksi keuangan nasabah, kemudian terdapat CS (Customer Services) atau bagian Deskman yang berfokus pada tugas melayani nasabah saat ingin membuka rekening baru, pengajuan pinjaman, mentransfer uang serta kegiatan menabung, Security bagian keamanan demi menjaga kondisi agar tetap kondusif, kemudian Staff Back office yang bertugas untuk menyusun laporan-laporan keuangan nasabah dengan baik dan tepat serta masih banyak lainnya.

b) Pelayanan Eksternal yaitu pelayanan yang kemudian diberikan kepada nasabah atau setiap pelanggan sebagai konsumen yang disalurkan melalui dengan menyediakan atau memberikan pelayanan kepada nasabah menggunakan Automated Teller Machine atau biasa diketahui sebagai mesin ATM (Anjungan Tunai Mandiri), atau biasanya juga dilakukan dengan cara mobil pelayanan jasa perusahaan Bank Rakyat Indonesia yang berjalan keliling di sekitar lingkungan masyarakat dalam rangka mempermudah proses pelayanan jasa yang ditawarkan dalam operasional perusahaan BRI tersebut.

\section{Perilaku Konsumen terhadap Kualitas Pelayanan Jasa Perusahaan Bank Rakyat Indonesia (BRI).}

Pada dasarnya, dapat diyakini oleh penulis bahwa mengenai konsep dari konsumen itu sendiri dapat ditekankan sebagai orang yang memiliki hak untuk pemenuhan kebutuhannya saat akan membeli produk atau jasa dari suatu perusahaan (Company) manapun. Maka dari itu, penulis akan mempertegas kembali bahwa terdapat beberapa hak konsumen dalam kualitas pelayanan jasa perusahaan Bank Rakyat Indonesia diantaranya sebagai berikut, pertama yakni hak kenyamanan dan keamanan saat memperoleh layanan peminjaman keuangan dengan pihak BRI maupun layanan yang aman saat akan menabung uang baik seperti yang terjadi pada contoh kasus ATM hilang kemudian bisa langsung menelpon pihak pusat atau yang biasa diketahui sebagai pusat informasi dan khusus pelayanan krusial Call Center dalam memprioritaskan setiap nasabah manapun. Kemudian melindungi saat ATM tertelan dan cepat dengan sigap diblokir kemudian diamankan uang tabungan nasabah tersebut. Hal-hal kecil ini adalah contoh sederhana yang sangat menunjang nilai profesionalitas layanan jasa yang diberikan oleh pihak perusahaan Bank Rakyat Indonesia. Kemudian yang kedua yakni, hak untuk mendapatkan informasi yang jelas, benar serta transparan seperti pada saat proses peminjaman uang untuk membangun usaha maka nasabah berhak tahu berapa cicilan pinjaman yang harus dibayar setiap bulannya sertakan dengan bunga $\mathrm{n}$ yang harus dibayar dengan jumlah yang sangat akurat dan tepat. Sehingga, dapat diketahui nantinya bagaimana kenyamanan yang dirasakan oleh pihak nasabah sebagai pihak yang akan menunjukkan perilakunya sebagai konsumen (Customer) dalam perusahaan Bank Rakyat Indonesia tersebut. Dalam hal ini terdapat beberapa faktor krusial yang menunjukkan perilaku konsumen terhadap kualitas pelayanan jasa Bank Rakyat Indonesia diantaranya terdapat Kinerja, Ciri khas atau karakteristik khusus saat memberikan pelayanan oleh pihak perusahaan Bank Rakyat Indonesia kepada pihak nasabah, nilai Estetika ataupun sikap Manner yang ditunjukkan oleh petugas Bank dalam memberikan pelayanan jasa seperti memberikan itikad yang baik dengan mengucapkan salam dan bertanya dengan tata krama yang tepat. Dengan begini maka sudah pasti perilaku konsumen sebagai aktor yang berperan sebagai nasabah akan memberikan penilaian yang baik pula kepada pihak perusahaan Bank Rakyat Indonesia (BRI). 


\section{Kesimpulan}

Dalam penulisan makalah yang berfokus pada parameter Perusahaan Bank Rakyat Indonesia ini penulis menetapkan judul "Analisis Teori komunikasi pemasaran Terhadap Kualitas Pelayanan Jasa PT. Bank Rakyat Indonesia". Pada dasarnya penulis akan membahas eksistensi Bank di Indonesia yang saat ini sangat diperlukan karena kehadirannya kini sudah menjadi sebuah kebutuhan dan menjadi tempat ketergantungan bagi setiap warga negara yang ingin memiliki simpanan uang serta menabung untuk menjaga keuangan masa depannya. Kemudian, penulis menyadari bahwa dalam penulisan makalah ini diketahui bahwa salah satu komponen terpenting dari Bank adalah kegiatan pelayanannya dan maka dari itu pentingnya menjaga kualitas pelayanan jasa dalam Bank juga dapat mempengaruhi cara pandang konsumen yang bertindak sebagai nasabah dalam memberikan sebuah penilaian.

Hal ini dikarenakan kehadiran konsumen akan bisa dianalisis dari kepuasannya sebagai nasabah karena hal itu akan menjadi evaluasi purna beli penting dalam kegiatan operasional Bank karena terdapat nilai alternatif yang dipilih sekurang-kurangnya sama atau bisa melewati ekspektasi harapan dari para pelanggan, sedangkan nantinya jika ketidakpuasan ini timbul maka itu merupakan hasil (Outcome) yang tidak bisa memenuhi ekspektasi ataupun harapan dari para nasabah tersebut. Sehingga, hal ini berpengaruh secara tidak langsung dalam Studi ilmu komunikasi yang penulis yakini bahwa esensi konsumen sebagai bagian dari keberhasilan maupun kesuksesan seorang pelanggan yang setia dan terus berlangganan di suatu perusahaan adalah karena bisa mempercayai sistem pelayanan jasa yang diberikan selalu memenuhi ekspektasi pelanggan dan mengikuti perkembangan zaman atau bersifat fleksibel melalui sistem komunikasi pemasaran yang tepat.

Saran

Dalam penulisan jurnal yang berfokus pada parameter Perusahaan Bank Rakyat Indonesia ini penulis menetapkan judul "Analisis Teori komunikasi Pemasaran Pada Perilaku Konsumen Terhadap Kualitas Manajemen Pelayanan Jasa PT. Bank Rakyat Indonesia". Pada dasarnya penulis membahas makalah ini dengan menggunakan referensi yang bersumber dari sumber pustaka dan hasil analisis deskriptif dari kondisi yang sebenarnya terjadi dari berbagai bahan bacaan. Sehingga, hasil analisis ini sebagian besar secara teoritis telah membuktikan keberhasilannya yakni dengan menunjukkan kualitas pelayanan jasa dari perusahaan Bank Rakyat Indonesia ini akan sangat berpengaruh dari perilaku konsumen yang hadir dalam kegiatan operasional bank tersebut. Maka dari itu, dalam penulis karya tulis makalah ini tetap akan membutuhkan masukan dan saran perbaikan untuk kedepannya dari para akademisi kampus maupun dari pihak instansi akademisi lainnya baik seperti Dosen, Mahasiswa/(i) serta pembaca lainnya yang membutuhkan bahan tulisan ini sebagai sumber referensi tulisan. Saran ini diperlukan agar dimasa mendatang dapat disesuaikan dengan perkembangan kondisi yang terjadi di masyarakat.

\section{Daftar Pustaka}

Tim redaksi Indotesis.com. (2017/05/09). Pengertian dan Faktor-Faktor yang Mempengaruhi Perilaku Konsumen. Medium.com. Diakses pada 30 Juli 2021, dari https://medium.com/@ indotesis/pengertian-dan-faktor-yang-mempengaruhi-perilakukonsumen-5c6c56d179f7

Moleong, Lexy J. (2017). Metodologi Penelitian Kualitatif. Edisi Revisi. Yogyakarta: Penerbit Rosda.

Jogiyanto. (2018). Metodologi Penelitian Bisnis. Yogyakarta :BPFE Yogyakarta. 
Balqiah, Tengku Ezni \& Setyowardhani, Hapsari. (2017). Modul 1: Pemahaman Konsep dan Studi Perilaku Konsumen dalam Pengembangan Startegi Pemasaran.

Febriyanti, Wahyu \& Widiyati, Sri. (2019). Analisis Kepuasan Nasabah Atas Kualitas Layanan Internet Banking Pada PT. Bank Rakyat Indonesia (Persero) Tbk. Unit Banyumanik Semarang. Jurnal: Majalah Ilmiah. ISSN: 2302-9315. Vol. 7, No. 1. Tahun VII.

Muliati. (2017). Sistem Manajemen Mutu Dalam Peningkatan Kualitas Pelayanan Pada PT. BRI (Bank Rakyat Indonesia) Kantor Wilayah Makassar. Jurnal: Sosial dan Politk (ALQISTHI). ISSN: 2301-6876, Vol. 7 No. 2, Edisi Desember.

Munawaroh. (2017). Analisis Perilaku Nasabah Dalam Pengambilan Keputusan Terhadap Produk Pembiayaan (Studi pada PT. BNI Syariah kantor cabang Tanjung Karang). Skripsi. Publikasi: Universitas Islam Negeri Raden Intan Lampung. Diakses pada 30 Juli 2021, dari http://repository.radenintan.ac.id/2867/

Permana, Andikha Putra. (2018). Analisis Pelayanan Publik Pada Bank Rakyat Indonesia KCP Sultan Syarif Abdurachman Pontianak. Jurnal: Pembangunan dan Pemerataan. Vol. 7, No. 2.

Possumah, Nurcahya Hartaty \& Lamala, Cindi Rina Fricilia. (2019). Analisis Manajemen Dalam Keputusan Pemberian Kredit Pada PT. Bank Rakyat Indonesia (PERSERO) Tbk Unit Bualemo. Jurnal: Ilmiah Manajemen. DOI: 10.32529/emor.v2i1.188. Vol. 2, No. 1, Hal. 84-95.

Pratama, Kevin Aditya. (2018). Analisis Kualitas Pelayanan Terhadap Kepuasan Nasabah Bank Rakyat Indonesia Cabang Ponorogo. Skripsi. Publikasi: Universitas Islam Indonesia. $\begin{array}{lllll}\text { Diakses } & \text { pada } & 30 & \text { Juli }\end{array}$ https://dspace.uii.ac.id/bitstream/handle/123456789/9596/SKRIPSI\%20Kevin\%20Adity a\%20Pratama.pdf?sequence $=2 \&$ is Allowed $=y$

Rahmawati, Anita. (2020). Kualitas Pelayanan Bank Terhadap Kepuasan Nasabah Pada Sistem Antrian Tellerbank (Studi Kasus BRI Syariah Kantor Cabang Tanjung Karang). Tesis Undergraduate. Publikasi: IAIN Metro (Instituts Agama Islam Negeri).

Ramadhan, Aldi Feri, Dewi, Dian Nirmala \& Irawan. (2017). Analisis Kinerja PT Bank Rakyat Indonesia, Tbk Sebelum dan Sesudah Akuisisi. Jurnal: Akuntansi POLINELA (Politeknik Negeri Lampung).

Recha, Prettya \& Syafriandi. (2017). Analisis Kepuasan Nasabah Terhadap Kualitas Pelayanan PT. Bank Rakyat Indonesia (PERSERO) TBK Unit Semurup Dengan Pendekatan Analisis Korespondensi. Jurnal: UNIMUS (Universitas Muhammadiyah Semarang). ISBN: 978-602-61599-6-0.

Sumarwan, Ujang. Modul 1: Model Keputusan Manajemen. Publikasi: UT (Universitas Terbuka). 